\title{
A viewpoint on Indian ricegrass research: Its present status and future prospects
}

\author{
T.A. JONES
}

\section{Abstract}

Indian ricegrass (Oryzopsis hymenoides (Roem. \& Schult.) Ricker) is adapted to sandy arid areas of much of the western USA and is a highly desirable species on winter range sites. Seed is typically highly dormant. Mechanical dormancy has been reduced by mechanical and sulfuric acid scarification, and physiological dormancy has been reduced with stratification, giberellic acid, and kinetin. $A$ better understanding of the relationship between mechanical and physiological dormancy may lead to a practical procedure for breaking dormancy in harvested seed. Alternatively, a better understanding of environmental factors on seed production may lead to production of already low dormancy seed. Establishment success will also depend on development of appropriate seedbed management practices for various soils. Reduction of the currently large shattering loses would have a favorable impact on the economics of Indian ricegrass seed production. An interdisciplinary approsch including seed physiology, seedbed ecology, seed technology, and plant breeding can potentially solve these problems. The potential of seeding Indian ricegrass for improving rangelands can only be realized after low dormancy seed becomes available, appropriate seedbed management practices are developed, and seed shattering losses are reduced.

Key Words: Oryzopsis hymenoides, seed dormancy, seed retention, Stipa hymenoides, winter range.

\section{Biology and Variation}

The distribution of Indian ricegrass (Oryzopsis hymenoides (Roem. \& Schult.) Ricker (Cronquist et al. 1977) = Stipa hymenoides Roem. \& Schult. (Welsh et al. 1987)) extends from the Nebraska sandhills west to the eastern slopes of the Cascade and Sierra-Nevada ranges and from Mexico to Canada at elevations up to $3,000 \mathrm{~m}$ (Booth et al. 1980). It is the dominant perennial grass species of the low-elevation salt desert range of the sagebrush vegetation zone (Young and Evans 1984). Indian ricegrass is a cool-season grass found on soils that are neutral to mildly alkaline, low in water-holding capacity, low in clay content, high in bulk density, and with few rock fragments (Platou et al. 1986). Sites occupied by Indian ricegrass are warmer and drier than sites occupied by bluebunch wheatgrass (Pseudoroegneria spicata (Pursh) A. Löve) or Idaho fescue (Festuca idahoensis Elmer). Indian ricegrass sites receiving at least $200 \mathrm{~mm}$ average annual precipitation are more clayey and less rocky than drier Indian ricegrass sites. In the Kaiparowits Basin of southern Utah, Indian ricegrass was found on soils averaging 75\% sand (Jaynes and Harper 1978). Indian ricegrass was most often found on minimal slopes and in deep soils having a relatively low $\mathrm{pH}$ and clay content compared to other species on the site. Indian ricegrass is the dominant and often the only perennial grass found on areas of sand at low elevations in arid environments, but it is also the first perennial grass to invade clay soils infested with medusahead (Taeniatherum asperum (Simonkai) Nevski) (personal communication, J.A. Young).

Author is research geneticist, USDA-ARS Forage and Range Research Laboratory, Utah State University, Logan 84322-6300. Contribution of Utah Agr. Exp. Sta., Journal Paper 3875, and USDÁ-ARS, Forage and Range Research Laboratory.

Appreciation is extended to Alan Beetle, Laramie, Wyo., for the use of his personal index of Indian ricegrass references from the Journal of Range Management.

Manuscript accepted 10 Jamuary 1990.
Accessions have been collected by the USDA-ARS Native Grass Project (Logan, Utah) from loamy sands (20), sandy loams (19), sands (12), loams (10), clays (5), silt loams (2), sandy clay loams (2), and clay loams (2). Collections were made from clay soils in the vicinities of Winnemucca, Nevada (T-443); Dinosaur, Colorado (T-451); Nine Mile Gap, Colorado (T-453); Penrose, Colorado (T-469); and Moab, Utah (T-556). The soil pH at 72 collection sites ranged from 7.2 to 8.8. Electrical conductivity ranged from 0.2 to $3.1 \mathrm{mmho} / \mathrm{cm}$.

Indian ricegrass is a member of the Stipeae, considered by Barkworth and Everett (1987) as a tribe in the subfamily Arundinoideae. They consider current generic concepts in the tribe artificial and have reorganized the tribe based primarily on lemma epidermal patterns, but also on palea, leaf, and other characters. Indian ricegrass was allied with Stipa arida M.E. Jones, $S$. coronata Thurber, S. lettermanii Vasey, S. nevadensis B.L. Johnson, $S$. occidentalis Thurber, S. pinetorum M.E. Jones, S. scribneri Vasey, $S$. speciosa Trin. \& Rupr., S. thurberiana Piper, S. webberi (Thurber) B.L. Johnson and others in the Achnatherum speciesgroup. Such species as $O$. asperifolia Michx., $O$. canadensis (Poir.) Torr., $O$. exigua Thurber, $O$. micrantha (Trin. \& Rupr.) Thurber, o. miliaceum (L.) Aschers. \& Schweinf. (= Piptatherum miliaceum), O. pungens (Torr.) Hitchc., O. racemosa (J.E. Smith) Ricker, S. comata Trin. \& Rupr., S. leucotricha Trin. \& Rupr., S. neomexicana (Thurber) Scribn., S. pulchra Hitchc., S. spartea Trin., and $S$. viridula Trin. were placed in other species-groups. Various authors have considered Indian ricegrass as a member of Stipa, Eriocoma, and Milium as well as Oryzopsis (Cronquist et al. 1977).

\section{Physiology, Ecology, and Utilization}

Growth of established Indian ricegrass plants begins when soil temperatures at a $15-\mathrm{cm}$ depth remain at $4^{\circ} \mathrm{C}$ for 3 to 4 days (Pearson 1979). Plant height was positively and negatively correlated with soil temperature in the vegetative growth stages' early phase and late phase, respectively. Indian ricegrass adjusts to shifting sands by elongating basal internodes and producing adventitious roots at these nodes (Stoddart and Wilkinson 1938). Fungal hyphae are intimately associated with the root system of this species (Robertson 1976), and a rhizosheath is visible only a few days after germination. Nitrogen fixation is associated with the rhizosheath (Wullstein 1980). An ecotype from Chaco Canyon, New Mexico, had 2 and 3 times the root biomass of Nezpar and Paloma, respectively Orodho and Trlica (1990) Indian ricegrass has been reported to accumulate selenium (Hamilton and Beath 1963).

Indian ricegrass is well adapted to desert environments, flowers prolifically, and sets seed quickly. Unlike most other cool-season grasses, vernalization (exposure to cold) is not required for flowering. New panicles may continue to appear after the first panicles of the year are removed, though their abundance is highly genotypedependent. Flowering may continue late into the fall if environmental conditions are favorable. If conditions are less than favorable, seed can be produced within 10 to 11 weeks following the initiation of spring growth (Everett et al. 1980). Panicle appearance and flowering within each panicle is highly indeterminate. This allows the seeds to ripen over a lengthy time period and provides 
greater opportunity for successful seed production. Though collections have little variation in maturity date, considerable variation is present for panicle production in initial growth and in regrowth after clipping. Anthesis was delayed by soil temperatures above $10^{\circ} \mathrm{C}$ in the late vegetative growth phase, but not affected by soil temperatures in the early vegetative growth phase (Pearson 1979). Precipitation after 15 June increased growth but was too late to affect phenology. Moisture earlier in the season delayed anthesis.

Indian ricegrass is highly preferred by livestock and cures well for winter utilization (Cook et al. 1962, Robertson 1976, Booth et al. 1980), but its forage quality is not well documented. Palatability to sheep is not consistently high (Shewmaker et al. 1989). Overgrazing has greatly reduced the incidence of this species on native sites (Rogler 1960). Moderate (60\% herbage removed) 1 January clipping over a 3-year period was not deleterious, but both moderate and heavy ( $90 \%$ herbage removed) clipping 1 April and 1 May decreased live crown cover the following year (Cook and Child 1971). Even in the absence of grazing, this short-lived perennial usually begins declining by the fifth year (Robertson 1976), though West (1979) reported 33-year-old plants. In Chaco Canyon, New Mexico, 50 years of protection from heavy grazing did not result in genetic selection for herbivory tolerance Orodho and Trlica (1990).

Most attempts to establish Indian ricegrass have been unsuccessful because of high seed dormancy (Rogler 1960). Most successes have been in sites averaging greater than $300 \mathrm{~mm}$ precipitation annually (Plummer and Frischknecht 1952). Indian ricegrass is considered an excellent species for revegetation of mine spoils (Zemetra et al. 1983) and dunes (Young et al. 1983). Kinsinger (1962) reported a positive correlation between depth of seed (19 to $141 \mathrm{~mm}$ ) and height of foliage (70 to $361 \mathrm{~mm})$. Plants arising from shallow seeds produced more and thicker tillers. Soil moisture was not the only factor involved because the positive correlation was also measured in a well-watered greenhouse environment. Smigelski (1968) reported that seedlings in sand dunes germinate from seeds located at the top of a subsurface soil layer with moisture at field capacity. This layer exhibits stable temperatures and is insulated by an overlying layer of sand below permanent wilting point. The lower layer is moistened by winter precipitation and is covered in the spring by a dry upper layer deposited by wind. Most germinating seeds were found at the interface of the 2 layers, with roots being confined to the lower moist layer.

Heteromyid rodents were observed to cache Indian ricegrass seed in the Carson Desert of Nevada (McAdoo et al. 1983). Indian ricegrass seed was preferred when available. Nearly half of the cached seeds were naked, the lemmas and paleas being removed by the rodents. The caches were later excavated and consumed or the clump of germinating seedlings was grazed by the rodents. What appeared to be individual plants often were several plants which had germinated from a single cache. McAdoo et al. (1983) concluded that germination from these caches was the primary establishment method at this site.

\section{Breeding System, Varieties, and Hybridization}

Indian ricegrass does not demonstrate self-incompatibility and is probably highly self-fertilized (Jones and Nielson 1989). Because plants within collections are variable, they are probably mixtures of moderately to highly homozygous lines. Under mesic conditions, anthers may be exserted, permitting cross-pollination. But under hot, stressful conditions, pollination occurs before the flower opens; such behavior is termed ecological cleistogamy. Populations are mostly site-specific ecotypes (Robertson 1977, Booth et al. 1980). Chromosome number is $2 n=48$ (Johnson and Rogler 1943), plus supernumerary chromosomes which may be present (Johnson 1963). Indian ricegrass seeds may be long-lived, as evidenced by $38 \%$ germination of 26 -year-old seed held in uncontrolled storage (Hull 1973). However, Rogler (1960) reported germination below $10 \%$ after 12 years of storage.

Two varieties, Paloma and Nezpar, have been released by the United States Department of Agriculture Soil Conservation Service. Paloma was collected in 1957 at Florence, Colorado, and was released cooperatively in 1974 with the New Mexico state highway department and agricultural experiment stations in New Mexico, Colorado, and Arizona for its superior seed and forage production, establishment, and seedling vigor (Anonymous 1974). Nezpar was collected in 1935 at Whitebird, Idaho, and was released cooperatively in 1978 with the Idaho Agricultural Experiment Station for favorable stand establishment (Booth et al. 1980).

Hybrids with 10 Stipa species have been reported (Johnson 1962). Nielsen and Rogler (1952) reported a spontaneously chromosome-doubled hybrid of $S$. viridula $\times O$. hymenoides, which they named Mandan ricegrass. The amphiploid was meiotically regular with 65 bivalents, fertile, and true breeding. Seed dormancy appeared to be lower in the amphiploid than in either parent species. A single plant of a hybrid with $S$. neomexicana near Boulder, Colorado, (Weber 1957) has given rise to a fertile colonizing population of several dozen plants.

\section{Seed Dormancy}

Huntamer (1934) described 2 seed dormancy mechanisms operating in Indian ricegrass, a mechanical dormancy and a physiological (or embryo) dormancy. The mechanical dormancy is considered persistent over time (McDonald 1976) and is a result of the indurate lemma and palea, which prevent the penetration of $\mathrm{O}_{2}$ required for germination (Toole 1940, Fendall 1966). These workers have shown that the lemma and palea, however, do not inhibit water uptake. In contrast, physiological dormancy is known to decrease over time, but storage at low humidity and temperature slows the process (Robertson 1976, McDonald and Khan 1977). Stoddart and Wilkinson (1938) considered mechanical dormancy more important than physiological dormancy, but this may not be true in recently harvested seed (Jones et al. 1988). By comparing germination of intact (lemma and palea present) seed and naked (lemma and palea absent) seed within 6 accessions, these workers suggested a negative correlation between physiological and mechanical dormancy among accessions. Huntamer (1934) found accession with greater dormancy originated from drier sites, but Plummer and Frischknecht (1952) reported the reverse.

Mechanical dormancy can be virtually eliminated when the lemma and palea are removed from the seed because the pericarp is then easily ruptured (Stoddart and Wilkinson 1938, Young and Evans 1984). Freezing $\left(-20^{\circ} \mathrm{C}\right)$ and thawing $\left(43^{\circ} \mathrm{C}\right)$, boiling, enzyme, and peroxide treatments were ineffective in breaking mechanical dormancy (Stoddart and Wilkinson 1938, McDonald and Khan 1977). Scarification may be accomplished mechanically (Griffith and Booth 1988) or with acid, but the literature on the latter method is much more extensive. Both methods have the disadvantage of damaging the seed.

Scarification with sulfuric acid can greatly improve germination, despite greatly reduced protein synthesis in the treated seed (McDonald and Khan 1983). They reported 67\% germination of 2-year-old seed after $\mathbf{4 0}$ minutes of soaking in $67 \%$ sulfuric acid compared to a 5\% germination control. Young et al. (1983) found that acid scarification was unacceptably imprecise and rendered seed susceptible to pathogens. McDonald (1976) recommended a procedure that included grading the seeds according to size, acidscarifying each grade for an optimum length of time, applying gibberellic acid $\left(\mathrm{GA}_{3}\right)$ via acetone, and coating with $40 \%$ manganese ethylenebisdithiocarbamate (maneb) fungicide. Five accessions ranged from 36 to $91 \%$ germination after this treatment. Zemetra et al. (1983) applied this procedure without grading seed 
according to size in greenhouse and fall seeding experiments. Greenhouse germination of 6-month-old, 1-year-old, and 2-yearold seed increased from $8.4 \%, 28.0 \%$, and $50.2 \%$ to $50.2 \%, 30.9 \%$, and $66.8 \%$, respectively, after this treatment. The treatment, however, reduced emergence of 1 and 2-year-old seed in the fall-seeded field trial. The authors concluded that this treatment weakened the seed's ability to overwinter and did not recommend it for fall seeding. Toole (1940) believed acid scarification reduced physiological dormancy as well as mechanical dormancy because some scarified lots exhibited enhanced germination despite lemmas and paleas persisting following scarification.

Zemetra and Cuany (1984) investigated lemma thickness for determination of the appropriate duration of acid treatment. Mean lemma thickness among accessions ranged from 42 to $76 \mathrm{um}$. Most accessions with thinner lemmas came from the northern part of the species' distribution, but lemma thickness was unrelated to seed weight. Paloma's lemma was thicker than Nezpar's (Zemetra and Cuany 1984) and took longer to acid-scarify (Young et al. 1983). Lemma thickness was similar in seed produced at 2 Colorado locations.

Kinetin or $\mathrm{GA}_{3}$ in an acetone solution overcame physiological dormancy and increased germination of 1-year-old acid-scarified seed from $31 \%$ to $54 \%$ or $65 \%$, respectively (McDonald and $\mathrm{Khan}$ 1977). Hormones had no effect on unscarified seed. Stratification of 6-month-old seed gave germination ranging from 5 to $85 \%$ in 6 accessions (Rogler 1960), presumably by increasing endogenous gibberellins. Stratification also reduced the germination-inhibiting effect of light and had a much greater effect on mechanically scarified seed than unscarified seed (Shaw 1976). Fendall (1966) noted that fall plantings are generally much more successful than spring plantings. Booth et al. (1980) recommended fall-planting seed aged 4 to 6 years, but noted older seed could not emerge from depths as great as younger seed. Griffith and Booth (1988) suggested storage required for loss of physiological dormancy could be reduced if seed was scarified before storage. Treatment of seed with $\mathrm{KNO}_{3}$ does not improve germination (Huntamer 1934, Toole 1940).

Rogler (1960) rejected seed treatment procedures on the grounds that they would not find acceptance in the seed industry. He considered the development of a low-dormancy variety the only acceptable solution. Stoddart and Wilkinson (1938) argued that grading before sulfuric acid treatment was desirable but impractical for large quantities of seed.

Seed dormancy is considered the most important cause of the poor stand establishment which has limited the use of this species. Factors believed to influence seed dormancy are age of seed, seed polymorphism, seed production environment, and genotype. Older seeds require less acid scarification than recently harvested seeds (McDonald and Khan 1977, Young et al. 1983). This seems to imply that mechanical dormancy is not as persistent as once believed. Zemetra and Cuany (1984) found that 12 accessions ranged from 0.2 to $8.0 \%$ germination at 9 months of age, but increased to 44.0 to $74.5 \%$ at 42 months of age. Fifty strains of Indian ricegrass germinated $2.8 \%$ in year 1 and $47.4 \%$ in year 6 (Rogler 1960). After germination peaked, the rate of germination decline was approximately the same as the rate of germination increase before peak germination. A large strain $\times$ production year interaction for age of seed at peak germination was present.

Seed polymorphism is another factor associated with seed dormancy. Huntamer (1934) described big black (height greater than 2/3 of length) and small black (height less than 1/3 of length) seed polymorphisms. Big black seeds matured earlier and shattered more readily than small black seeds. Paloma is predominantly big black, while Nezpar has similar numbers of both types (Young and Evans 1984). Toole (1940) and Young and Evans (1984) found that small black seeds exhibited lower dormancy than big black seeds. Huntamer (1934), Stoddart and Wilkinson (1938), and Toole (1940) reported that, within an accession, small seeds required less acid scarification for germination than large seeds. However, Plummer and Frischknecht (1952) found that the correlation did not hold across 106 accessions. They concluded that the differences in seed size were heritable. Big black seeds are most common in the southern portion of the species' range, while small black are most common in the northern portion.

Seed production environment and genotype also affect dormancy. Seed low in mechanical dormancy has been produced at North Logan, Utah, (Jones et al. 1990). This suggests that the seed production environment has a large impact on dormancy. This effect, however, was genotype-dependent. Two accessions collected by the USDA-ARS Native Grass Project, T-26, $8 \mathrm{~km}$ southwest of Montello, Nevada, and T-43, $63 \mathrm{~km}$ north northwest of Eureka, Nevada, appear to have relatively low seed dormancy.

\section{Germination Testing}

Clark and Bass (1970) attempted to identify a method to maximize germination of Indian ricegrass. They recommended planting in sterile greenhouse potting soil $(1 / 3$ field soil $+1 / 3$ peat moss + $1 / 3$ sand) moistened with 100 ppm GAs. This test consists of a 4-week $5^{\circ} \mathrm{C}$ prechilling period followed by a 3-week $5 / 15^{\circ} \mathrm{C}$ alternating-temperature germination period conducted in the dark. One experiment showed no improvement of germination due to prechilling or removal of lemma and palea when planting in potting soil, though improvement was present when planting on or between blotter paper. This would suggest that physiological and mechanical dormancy are artifacts of the use of blotter paper, but in a second experiment prechilling improved germination in potting soil. This discrepancy is probably related to the use of different seed lots in the 2 experiments, indicating that the magnitude and relative importance of physiological and mechanical dormancy can vary greatly among seed lots. A major difficulty in much of the published work is that seed lots typically are not identified and their age is not specified. This greatly complicates interpretation of research results.

Ebener (1988) compared tetrazolium viability to viability determined by the method of the Association of Official Seed Analysts (AOSA), which is the sum of seed germinating in the Clark and Bass (1970) procedure plus nongerminating seed staining with tetrazolium. Viability determined by tetrazolium without the germination test averaged more than $13 \%$ greater than by the AOSA method. Ebener suggested that the discrepancy was due to embryo mortality during the germination test and proposed the use of the discrepancy as a measure of seed vigor of the seed lot, a large discrepancy indicating low vigor and a small discrepancy indicating high vigor.

\section{Seed Retention}

Because of its harsh native environment, much of the "seed" produced by Indian ricegrass is empty (Stoddart and Wilkinson 1938). Because this empty seed is much more persistent on the plant than heavy seed, it appears that Indian ricegrass holds its seed well; however, the reverse is actually true (Robertson 1977). Empty seeds are hollow and consist only of the lemma and palea. They are lighter in color than heavy seeds, and remain attached to the upper glume long after the glumes open. Heavy seeds will quickly abscise and are held midway between the glumes until shattered. Selection for genotypes with smaller glume pair angles can potentially reduce shattering (Whalley et al. 1990). This could result in more seeds on the plant at any one time and permit increased harvestable seed yield.

\section{Future Prospects}

Research topics for Indian ricegrass that merit attention include 
soil adaptation, persistence, seeding practices, environmental, and developmental factors affecting seed dormancy, and mechanisms of seed retention. While Indian ricegrass is primarily considered adapted to sandy soils, it may also be found on heavier soils. The importance of genotype $\times$ soil type interaction is unclear. If Indian ricegrass is highly ecotypic, one would expect large genotype $X$ environment interactions. However, a variety of accessions have not been evaluated over a variety of sites, so the importance of this interaction is open to speculation. An understanding of the genotype $X$ soil environment interaction would be of particular interest.

Persistence of this species is variable, but the factors affecting this variation have not been elucidated. Plant density and competition may be important. Other factors such as grazing and soilmoisture-temperature stresses should be considered.

An improved understanding of the seedbed ecology of this species could lead to more effective cultural practices for stand establishment. Factors such as season of planting, depth of seeding, soil texture, soil moisture, soil temperature, seed production environment, and genotype are probably highly interactive. An understanding of the importance of these factors to stand establishment, both individually and in combination, is of critical importance.

High germinability of seed lots used for revegetation is desired for favorable stand establishment even if seed dormancy is a feature of adapted genetic material (Roundy and Call 1988). Although considerable research has been directed at seed dormancy in Indian ricegrass, a practical method of breaking dormancy without seed damage has not been identified. The alternate approach of understanding what causes dormancy during seed production in hopes of circumventing it should be pursued as well. If mechanical dormancy could be avoided by seed production practices, stand establishment should improve since physiological dormancy can be broken over winter with late fall-seeded plantings. The possibility of production of seed initially low in mechanical dormancy and any subsequent breakdown over time need to be investigated further. Even if varieties could be bred for low seed dormancy, this would not necessarily be desirable following initial establishment, so some nongenetic means of controlling dormancy in seed intended for revegetation would be the preferred solution.

Physiological dormancy should be separated from mechanical dormancy in such experiments by comparing germination of naked and intact seed (Jones et al. 1988) or by comparing germination of stratified and unstratified seed. Use of naked seed eliminates mechanical dormancy, leaving primarily physiological dormancy, and stratification at least partially eliminates physiological dormancy, leaving mechanical dormancy plus residual physiological dormancy. A better understanding of the interaction between mechanical and physiological dormancy is desirable since they may be related (Griffith and Booth 1988, Jones et al. 1988). Conceivably the interaction between the 2 types of dormancy could be exploited to overcome dormancy in harvested seed.

Indian ricegrass seed is expensive, not only because stands are difficult to establish, but also because the indeterminate flowering pattern and poor seed retention prohibit harvest of much of the actual seed production. The high price of seed combined with the high probability of stand failure has discouraged seeding of this species. Of course there is the additional challenge of establishing a stand in the arid environments where Indian ricegrass offers the greatest advantages over other grass species. Improving harvestable seed yield of Indian ricegrass would help increase interest in this species. After establishment, total seed yield, not harvestable seed yield, is more important because of opportunities for seedling recruitment and for recovery of the population after disturbance.

Introduction of additional Indian ricegrass varieties will have little favorable impact until progress is made on seed dormancy and seed retention. An interdisciplinary approach encompassing the disciplines of seed physiology, seedbed ecology, seed technology, and plant breeding is required to address these problems. In summary, before Indian ricegrass assumes an important place in range revegetation efforts, 3 conditions must be fulfilled: dependable sources of low dormancy seed must be available, seedbed management practices appropriate for various soils must be developed, and a plant material/management practice package must be implemented which minimizes seed shattering losses.

\section{Literature Cited}

Anonymous. 1974. Notice of naming and release of 'Paloma' Indian ricegrass for stabilization and range forage. United States Department of Agriculture-Soil Conservation Service. Los Lunas, N.Mex.

Barkworth, M.E., and J. Everett. 1987. Evolution in the Stipeae: Identification and relationships of its monophyletic taxa. ch. 23 In: T. R. Soderstrom, K.W. Hilu, C.S. Campbell, and M.E. Barkworth (eds.) Grass systematics and evolution. Smithsonian Institution Press, Washington, D.C.

Booth, D.T., C.G. Howard, and C.E. Mowry. 1980. 'Nezpar' Indian ricegrass: Description, justification for release, and recommendations for use. Rangelands 2:53-54.

Clark, D.C., and L.N. Bass. 1970. Germination experiments with seeds of Indian ricegrass, Oryzopsis hymenoides (Roem. and Schult.) Ricker. J. Seed Technol. 60:226-239.

Cook, C.W., and R.D. Child. 1971. Recovery of desert plants in various states of vigor. J. Range Manage. 24:339-343.

Cook, C.W., K. Taylor, and L.E. Harris. 1962. The effect of range condition and intensity of grazing upon daily intake and nutritive value of the diet on desert ranges. J. Range Manage. 15:1-6.

Cronquist, A., A.H. Holmgren, N.H. Holmgren, J.L. Reveal, P.K. Holmgren. 1977. Intermountain flora, vascular plants of the Intermountain West, USA. vol. 6. The monocotyledons. Columbia Univ. Press, New York.

Ebener, W.C. 1988. Comparison of viability estimators on Indian ricegrass, Oryzopsis hymenoides, seeds. M.S. Thesis. Colorado State Univ., Fort Collins.

Everett, R.L., P.T. Tueller, J.B. Davis, and A.B. Brunner. 1980. Plant phenology in galleta-shadscale and galleta-sagebrush associations. $J$. Range Manage. 33:446-450.

Fendall, R.K. 1966. An investigation into the site and cause of seed dormancy of Stipa viridula and Oryzopsis hymenoides. Ph.D. Diss. North Dakota State Univ., Fargo. (Diss. Abstr. 26:3569-3570).

Griffith, L.W., and D.T. Booth. 1988. Indian ricegrass seed damage and germination responses to mechanical treatments. J. Range Manage. 41:335-337.

Hamilton, J.W., and D.A. Beath. 1963. Uptake of available selenium by certain range plants. J. Range Manage. 16:261-265.

Hull, A.C., Jr. 1973. Germination of range plant seeds after long periods of uncontrolled storage. J. Range Manage. 26:198-200.

Huntamer, M.Z. 1934. Dormancy and delayed germination of Oryzopsis hymenoides. M.S. Thesis. State College of Washington, Pullman.

Jaynes, R.A., and K.T. Harper. 1978. Patterns of natural revegetation in arid southeastern Utah. J. Range Manage. 31:407-411.

Johnson, B.L. 1962. Natural hybrids between Oryzopsis and Stipa. II. Oryzopsis hymenoides $\times$ Stipa nevadensis. Amer. J. Bot. 49:540-546.

Johnson, B.L. 1963. Natural hybrids between Oryzopsis and Stipa. III. Oryzopsis hymenoides $X$ Stipa pinetorum. Amer. J. Bot. 50:228-234.

Johnson, B.L., and G.A. Rogler. 1943. A cyto-taxonomic study of an intergeneric hybrid between Oryzopsis hymenoides and Stipa viridula. Amer. J. Bot. 30:49-56.

Jones, T.A., R. Hill, and D.C. Nielson. 1988. Germination of intact and naked seed of Indian ricegrass. J. Seed Technol. 12:114-119.

Jones, T.A., and D.C. Nielson. 1989. Self-compatibility in 'Paloma' Indian ricegrass. J. Range Manage. 42:187-190.

Jones, T.A., R.D.B. Whalley, and D.C. Nielson. 1990. Low mechanical dormancy in 1988 Indian ricegrass seed. Abstr. Soc. Range Manage. No. 355. Reno, Nev.

Kinsinger, F.E. 1962. The relationship between depth of planting and maximum foliage height of seedlings of Indian ricegrass. J. Range Manage. 15:10-13.

McAdoo, J.K., C.C. Evans, B.A. Roundy, J.A. Young, and R.A. Evans. 1983. Influence of heteromyid rodents on Oryzopsis hymenoides germination. J. Range Manage. 36:61-64.

McDonald, M.B., Jr. 1976. Improving the germination of Indian ricegrass seeds. J. Seed Technol. 1:44-54. 
McDonald, M.B., Jr., and A.A. Khan. 1977. Factors determining germination of Indian ricegrass seeds. Agron. J. 69:558-563.

McDonald, M.B., Jr., and A.A. Khan. 1983. Acid scarification and protein synthesis during seed germination. Agron. J. 75:111-114.

Nietsen, E.L., and G.A. Rogler. 1952. An amphidiploid of X Stiporyzopsis. Amer. J. Bot. 39:343-348.

Orodho, A.B., and M.J. Trlica. 1990. Clipping and long-term grazing effects on biomass and carbohydrate reserves of Indian ricegrass. J. Range Manage. 43:52-57.

Pearson, L.C. 1979. Effects of temperature and moisture on phenology and productivity of Indian ricegrass. J. Range Manage. 32:127-134.

Platon, A.K., P.T. Tueller, and S.G. Leonard, and R.L. Miles. 1986. Soil properties associated with six common grasses of the Great Basin. J. Soil Water Conserv. 41:417-421.

Plummer, A.P., and N.E. Frischknecht. 1952. Increasing field stands of Indian ricegrass. Agron. J. 44:285-289.

Robertson, J.H. 1976. The autecology of Oryzopsis hymenoides. Mentzelia 2:18-21, 25-27.

Robertson, J.H. 1977. Indian ricegrass-casanova of the western range. Rangeman's J. 4:138-139.

Rogler, G.A. 1960. Relation of seed dormancy of Indian ricegrass ( Oryzopsis hymenoides (Roem. \& Schult.) Ricker) to age and treatment. Agron. J. 52:470-473.

Roundy, B.A., and C.A. Call. 1988. Revegetation of arid and semiarid rangelands. ch. 24 In: P.T. Tueller (ed.) Vegetation science applications for rangeland analysis and management. Kluwer Academic Publishers, Dordrecht, Netherlands.

Shaw, N.L. 1976. An investigation of factors affecting the germination of Oryzopsis hymenoides (Roem. and Schult.) Ricker, accession P-2575. M.S. Thesis. Idaho State Univ., Pocatello.
Shewmaker, G.E., H.F. Mayland, R.C. Rosenau, and K.H. Asay. 1989. Silicon in C-3 grasses: Effects on forage quality and sheep preference. J. Range Manage. 42:122-127.

Smigelski, L.B. 1968. Field observations and laboratory studies on growth and tillering in seedlings of Oryzopsis hymenoides as affected by selected environmental factors of the sand dunes of Lynndyl, Utah. M.S. Thesis. Brigham Young Univ., Provo, Utah.

Stoddart, L.A., and J.J. Wilkinson. 1938. Inducing germination in Oryzopsis hymenoides for range reseeding. J. Amer. Soc. Agron. 30:763-768.

Toole, V.K. 1940. The germination of seed of Oryzopsis hymenoides. J. Amer. Soc. Agron. 32:33-41.

Weber, W.A. 1957. A new intergeneric natural hybrid involving Oryzopsis and Stipa (Gramineae). Rhodora 59:273-277.

Welsh, S.L., N.D. Atwood, L.C. Higgins, S. Goodrich. 1987. A Utah flora. Great Basin Nat. Mem. No. 9. Brigham Young Univ., Provo, Utah.

West, N.E. 1979. Survival patterns of major perennials in salt desert shrub communities of southwestern Utah. J. Range Manage. 32:442-445.

Whalley, R.D.B., T.A. Jones, D.C. Nielson, and R.J. Mueller. 1990 . Seed abscission and retention in Indian ricegrass. J. Range Manage. 43:291-294.

Wullstein, L.H. 1980. Nitrogen fixation (acetylene reduction) associated with rhizosheaths of Indian ricegrass used in stabilization of the Slick Rock, Colorado, tailings pile. J. Range Manage. 33:204-206.

Young, J.A., and R.A. Evans. 1984. Germination of seeds of 'Paloma' and 'Nezpar' Indian ricegrass. J. Range Manage. 37:19-21.

Young, J.A., R.A. Evans, and B.A. Roundy. 1983. Quantity and germinability of Oryzopsis hymenoides seed in Lahontan sands. J. Range Manage. 36:82-86.

Zemetra, R.S., and R.L. Cuany. 1984. Variation in lemma thickness in Indian ricegrass: Implications for dormancy, scarification, and breeding. Crop Sci. 24:1082-1084.

Zemetra, R.S., C. Havstad, and R.L. Cuany. 1983.Reducing seed dormancy in Indian ricegrass (Oryzopsis hymenoides). J. Range Manage. 36:239-241.

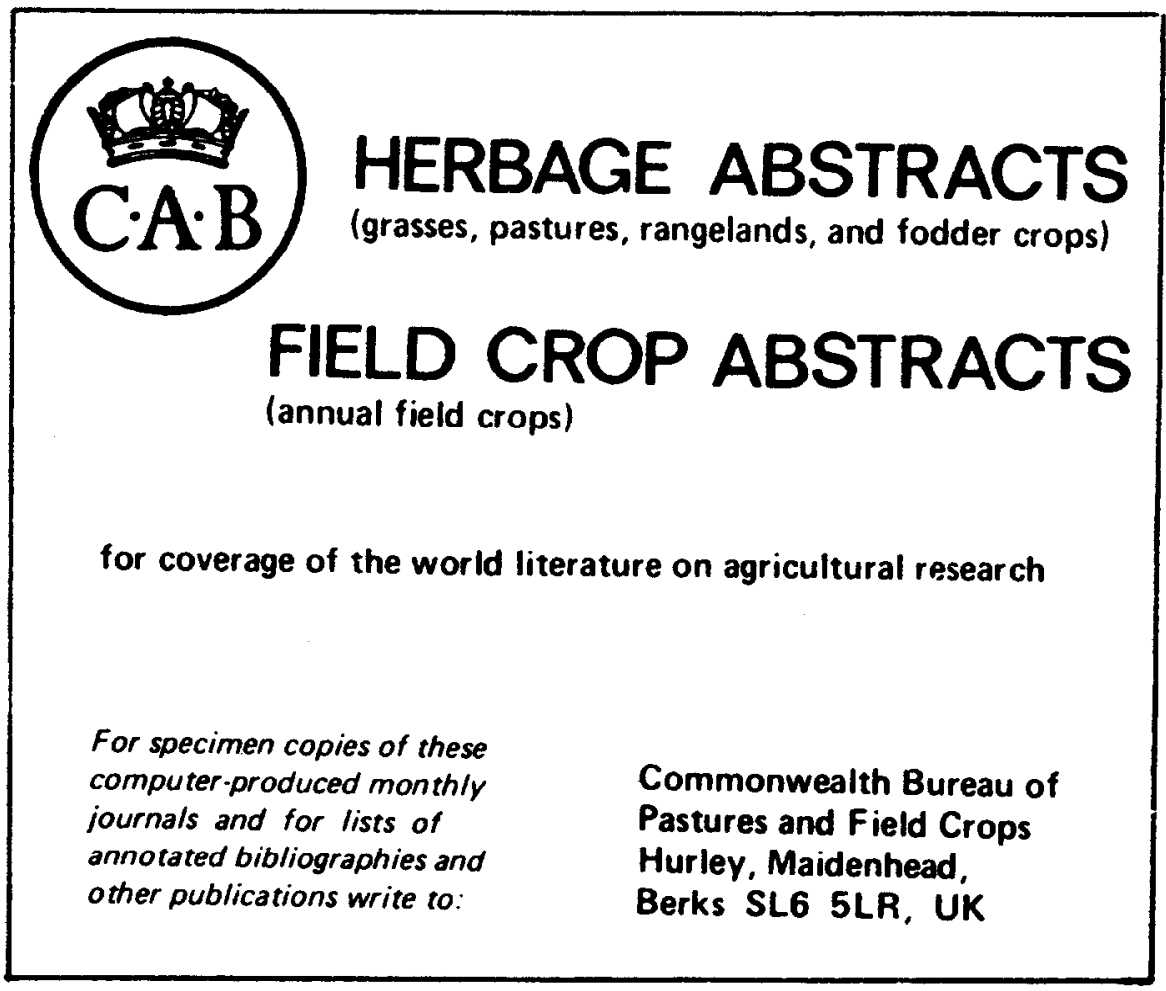

